Archive for

Organic Chemistry
Arkivoc 2018, part v, 0-0

to be inserted by editorial office

\title{
Insights into the triple self-condensation reaction of thiophene-based methyl ketones and related compounds
}

\author{
Anita Andicsová-Eckstein, ${ }^{a}$ Daniel Végh, ${ }^{b}$ Alžbeta Krutošíková, ${ }^{c}$ and Zita Tokárová*c \\ ${ }^{a}$ Polymer Institute, Slovak Academy of Sciences, 84541 Bratislava, Slovakia \\ ${ }^{b}$ Institute of Organic Chemistry, Catalysis and Petrochemistry, Faculty of Chemical and Food Technology, \\ Slovak University of Technology, 81237 Bratislava, Slovakia \\ ${ }^{c}$ Department of Chemistry, Faculty of Natural Sciences, University of SS Cyril and Methodius, \\ 91707 Trnava, Slovakia \\ Email: zita.tokarova@ucm.sk
}

Received 02-05-2018

Accepted 04-14-2018

Published on line 06-09-2018

\section{Abstract}

The acid catalysed triple self-condensation of 1-thien-2-ylethanone (2-acetylthiophene) and five related compounds is presented. Tetrachlorosilane used as the Lewis acid produces dry hydrogen chloride which catalyzes the self-condensation process. Depending on the reaction conditions and the substitution of the carbonyl substrates, the reaction can proceed as a $[2+2+2]$ cyclotrimerization towards $C_{3}$-symmetric $1,3,5-$ trisubstituted benzenes, or as the single-type aldol condensation leading to 1,3-disubstituted $(E)$ - 6 -methylchalcones. This is important for the design of new aromatic/olefinic compounds beyond the model structures. Synthesis of 4'-fluoro-3,5-di-(2-thienyl)biphenyl through a mixed-type aldol reaction using erbium triflate is discussed. Mechanistic rationale is provided.
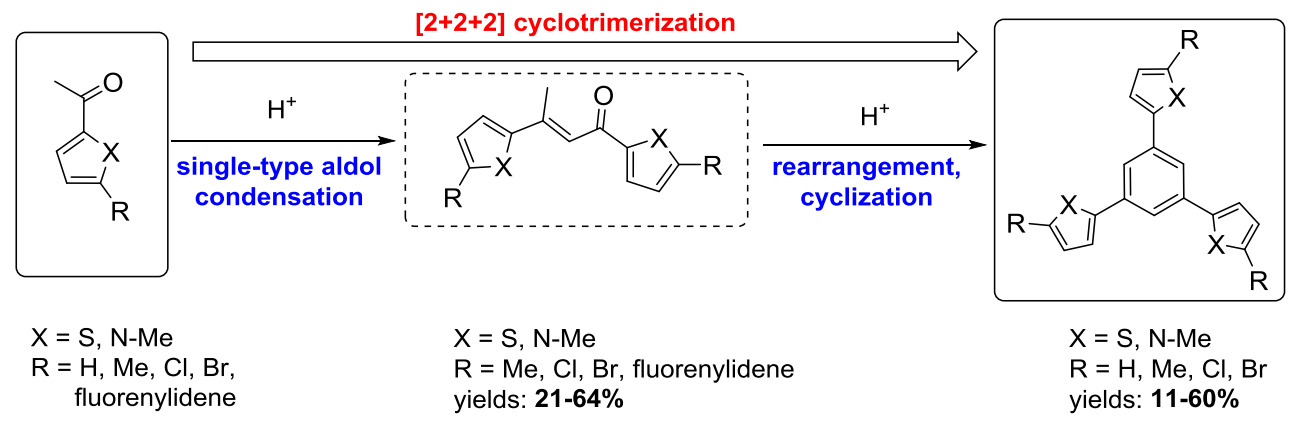

Keywords: [2+2+2] Cyclotrimerization, aldol condensation, 1,3,5-trisubstituted benzene, 6-methylchalcone 


\section{Introduction}

Star-shaped molecules based on 1,3,5-triarylbenzenes have long been recognized as a family of amorphous glasses stable above room temperature. ${ }^{1,2}$ The bioisosteric replacement of benzene by thiophene has extended the family of $C_{3}$-symmetric compounds ${ }^{3,4}$ and their applications in electroluminescent (EL) devices, ${ }^{5}$ liquid crystalline materials ${ }^{6}$ and as fluorescent probes. ${ }^{7}$ In contrast to polymers used in similar applications, amorphous molecular materials are pure materials with well-defined molecular structures and definite molecular weights without any distribution. Consequently, 1,3,5-tri(het)arylbenzenes serve as versatile platforms in the design of organic light emitting diodes (OLEDs), ${ }^{8,9}$ dendrimers, ${ }^{10}$ polycyclic aromatic hydrocarbons (PAH), ${ }^{11}$ bulky ligands ${ }^{12}$ and truxenes (derivatives of 10,15 -dihydro-5H-diindeno[1,2- $a ; 1^{\prime}, 2^{\prime}$ c]fluorene). ${ }^{13}$ The classical one-directional convergent synthetic approach, originally developed by Clapps and Morton, ${ }^{14}$ is that most frequently reported in the literature.

The $[2+2+2]$ cyclotrimerization of acetophenones and related compounds is expected to have outstanding potential because of its high atom economy and broad reaction scope. ${ }^{15}$ The triple self-condensation of starting acetophenones (AP) and hetaryl methyl ketones (HetAP) takes place mostly in ethanol using Brønsted or Lewis acids such as common $\mathrm{SiCl}_{4},{ }^{16-20} \mathrm{TiCl}_{4}{ }^{21,22} p-\mathrm{TsOH}^{23}$ and variations on more complex structures. ${ }^{23-28}$ Although these processes provide regioselective approaches to polysubstituted aromatic compounds, as has been presented in a large number of studies, ${ }^{16-32}$ there are some limitations including low yields, long reaction times, harsh reaction conditions, use of expensive metal catalysts, tedious work-up, and formation of side products.

It is generally known that $[2+2+2]$ cyclotrimerization involving bulky substrates is not a trivial task. The presence of a bulky substituent in the structure of the starting ketone can change the reactivity in favour of formation of appropriate (E)- 6 -methylchalcones (dypnones), derivatives of $(E)$-1,3-diphenyl-2-buten-1-one. ${ }^{33}$ This is because the triple self-condensation of acetophenones (AP) or hetaryl methyl ketones (HetAP), respectively, under mild reaction conditions (ambient temperature, efficient catalysis) occurs as a stepwise process, as was independently highlighted by Wu et al. ${ }^{34}$ and Wagh and Akamanchi. ${ }^{35}$ The acid catalyzed single-type aldol condensation of two equivalents of starting carbonyl compounds AP or HetAP towards the formation of (E)-B-methylchalcones (BMC) occurs first, followed by subsequent enolizazion and rearrangement of $B M C$ into final 1,3,5-triarylbenzenes (TAB) or 1,3,5-trihetarylbenzenes (THetAB). The bulky substitution as well as the electron-withdrawing substituents in the structure of acetophenones inhibit the second aldol reaction affording only the corresponding $(E)-6$-methylchalcones. ${ }^{34}$ There are two possibilities of cyclization, i.e. two equivalents of $(E)-B$-methylchalcone reacts to create $C_{3}$-symmetric benzenes (Scheme 1 , $A)^{34}$ or a molecule of the key intermediate dypnone undergo condensation with another molecule of the carbonyl substrate (Scheme $1, \mathrm{~B}) .^{35}$

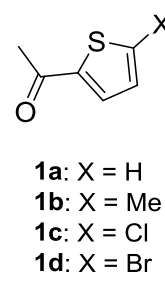

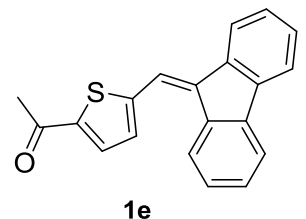

$1 \mathrm{e}$

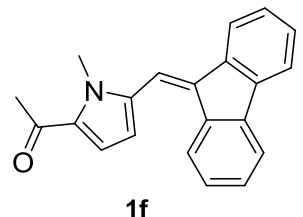

$1 f$

Figure 1. Structures of the starting carbonyl substrates under investigation. 
The formation of (E)-B-methylchalcones/dypnones during the process of cyclotrimerization is indeed underrated. Besides which, dypnone-involved organic synthesis is important further i.e. in a mixed-type aldol condensation towards unsymmetrically branched 1,3,5-trisubstituted benzenes, ${ }^{36}$ in the reduction towards diols ${ }^{37}$ or in the synthesis of allycyclic azides. ${ }^{38}$ In this regard, we have studied the process of the triple selfcondensation of hetaryl methyl ketones in the construction of either $C_{3}$-symmetric 1,3,5-trihetaryl benzenes or 1,3-bishetaryl (E)-6-methylchalcones/dypnones, or the mixture of the two possible compounds. Thien-2-ylethanone $\mathbf{1 a}$ and its C5 methyl- and halogen-substituted derivatives $\mathbf{1} \mathbf{b}$ - $\mathbf{d}$ were selected for our investigations under the different experimental conditions (Figure 1), either affecting the triple self-condensation by tetrachlorosilane $\left(\mathrm{SiCl}_{4}, 2-4\right.$ equiv.) combined with a solvent change (ethanol, ethanol/toluene mixture, 2ethoxyethanol) or by use of trifluoromethanesulfonic acid as a Brønsted acid catalyst (TFSA- $\mathrm{CF}_{3} \mathrm{SO}_{3} \mathrm{H}, 2 \mathrm{~mol} \%$ ) in toluene. In fact, $\mathrm{SiCl}_{4}$ and related weak Lewis acids in anhydrous alcohols produce controlled amount of dry hydrogen chloride $(\mathrm{g})$ acting as the acid catalyst in aldol-type condensations. ${ }^{39,40}$ Our study was extended employing 1-[5-(fluoren-9-ylidenemethyl)thien-2-yl]ethanone (1e) and 1-[5-(fluoren-9-ylidenemethyl)-1methyl-1H-pyrrol-2-yl]ethanone (1f) with a bulky fluorenylidenemethyl substituent at the C5 position of the thiophene and pyrrole rings (Figure 1), to examine the effect of the substitution on the reaction. The synthesis of 1,3,5-unsymmetrically substituted benzene is presented according to a mixed-type aldol condensation of the appropriate $(E)$ - 6 -methylchalcone and $p$-fluoroacetophenone.

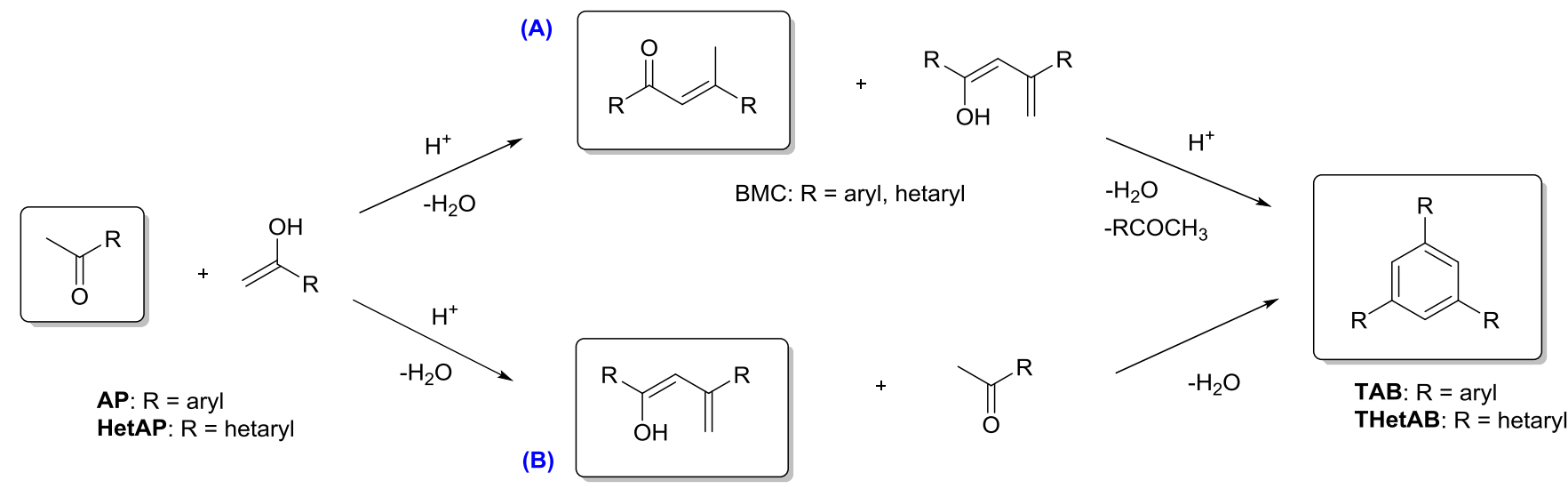

Scheme 1. $[2+2+2]$ Cyclotrimerization reaction of acetophenones and related compounds. Two possible routes to $C_{3}$-symmetric benzene formation are highlighted. ${ }^{34,35}$

\section{Results and Discussion}

\section{Effects of solvent, temperature and reaction time}

The $[2+2+2]$ cyclotrimerization of starting ketones $\mathbf{1 a - d}$ was carried out at room temperature $\left(25^{\circ} \mathrm{C}\right)$. The same approach with ketones $\mathbf{1 e}$ and $\mathbf{1 f}$ was conducted at $100{ }^{\circ} \mathrm{C}$. Generally, a relatively low temperature of the triple self-condensation towards 1,3,5-triarylbenzenes has to be maintained to form thermodynamically stable enol-silyl ether reactive intermediates of the excited state followed by in situ formation of gaseous $\mathrm{HCl}^{17,36,41}$ Although in the triple self-condensation process promoted by $\mathrm{SiCl}_{4}$ as the weak Lewis acid, ethanol proves to be the most universal solvent (Method A), ${ }^{18,19,36,39}$ the solubility of some hetaryl methyl ketones 1a-f in ethanol might be insufficient. Since the enhanced solubility of substrates together with the activity of tetrachlorosilane was crucial, we performed the $[2+2+2]$ cyclotrimerization with the starting substrates $1 \mathbf{a}-\mathbf{d}$ in 
a mixture of ethanol/toluene (Method $B)^{16,20}$ as well as by using 2-ethoxyethanol instead of ethanol (Method C). Use of a double and threefold excess of $\mathrm{SiCl}_{4} / \mathrm{EtOH}$ (Method $\mathrm{A}$ and $\mathrm{B}$ ) leads directly to 1,3,5-triarylbenzenes 3a-d, ${ }^{3}$ while use of excess of catalyst (4 equiv.) in 2-ethoxyethanol (Method C) gave good yields of Bmethylchalcones $\mathbf{2 b - d}{ }^{17,36}$ Since, fluorenylidene-substituted hetaryl methyl ketones $\mathbf{1 e}$ and $\mathbf{1 f}$ were insoluble in the solvents used according to Methods $A-C$, we turned to Method D, performing the reaction with trifluoromethane sulfonic acid (TFSA, $2 \mathrm{~mol} \%$ ) in toluene. The optimal reaction time during which the formation of unidentifiable polymers was suppressed was $14 \mathrm{~h}$ with $\mathrm{SiCl}_{4}$ (Methods $\mathrm{A}-\mathrm{C}$ ) and $30 \mathrm{~h}$ with $\mathrm{CF}_{3} \mathrm{SO}_{3} \mathrm{H}$ (Method D). The results on reaction conditions for $\mathbf{1 a}-\mathbf{f}$ are summarized in Table 1.

Table 1. The reaction conditions of [2+2+2] cyclotrimerization of thiophene-based methyl ketones 1a-e and pyrrolyl substrate $\mathbf{1 f}$

\begin{tabular}{|c|c|c|c|c|}
\hline \multirow[t]{2}{*}{ Method } & \multirow[t]{2}{*}{ Reaction conditions } & \multirow[t]{2}{*}{ Solvent } & \multirow{2}{*}{ Substrat } & Product / Process \\
\hline & & & & 1 \\
\hline $\begin{array}{l}\text { Method A } \\
\text { ref. }^{18,19,36,39}\end{array}$ & $\begin{array}{l}\mathrm{SiCl}_{4}(0.078 \text { mol, } 2 \text { equiv. }), \\
14 \mathrm{~h}, 25^{\circ} \mathrm{C}\end{array}$ & $\mathrm{EtOH}$ & $\begin{array}{l}1 \mathrm{a} \\
1 \mathrm{~b} \\
1 \mathrm{c}\end{array}$ & $\begin{array}{l}\mathbf{3 a} / \mathrm{TSC}^{\mathrm{a}} \\
\mathbf{3 b} / \mathrm{TSC}^{\mathrm{a}} \\
\mathbf{3 c} / \mathrm{TSC}^{\mathrm{a}}\end{array}$ \\
\hline $\begin{array}{l}\text { Method B } \\
\text { ref. }^{16,20}\end{array}$ & $\begin{array}{l}\mathrm{SiCl}_{4}(0.117 \text { mol, } 3 \text { equiv. }), \\
14 \mathrm{~h}, 25^{\circ} \mathrm{C}\end{array}$ & $\begin{array}{c}\text { EtOH/PhMe } \\
(50: 50)\end{array}$ & $\begin{array}{l}1 \mathrm{a} \\
1 \mathrm{~d}\end{array}$ & $\begin{array}{l}\mathbf{2 a} \quad / \\
\text { condensation }^{\mathrm{b}} \\
\mathbf{3 d} / \mathrm{TSC}^{\mathrm{a}}\end{array}$ \\
\hline Method C & $\mathrm{SiCl}_{4}(0.156 \mathrm{~mol}, 4$ equiv. $)$, & 2-Ethoxyethanol & $\begin{array}{l}1 \mathrm{a} \\
1 \mathrm{~b}\end{array}$ & $\begin{array}{l}\mathbf{3 a} / \operatorname{TSC}^{\mathrm{a}} \\
\mathbf{2} \mathbf{b}\end{array}$ \\
\hline & & & $1 \mathrm{c}$ & condensation $^{b}$ \\
\hline & & & $1 d$ & $2 c /$ aldol condensation $^{b}$ \\
\hline & & & & 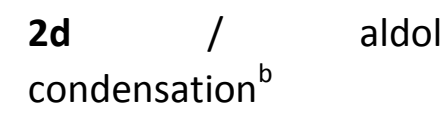 \\
\hline Method D & $\mathrm{CF}_{3} \mathrm{SO}_{3} \mathrm{H}(0.1 \mathrm{mmol}, 2 \mathrm{~mol} \%)$ & PhMe & $1 e$ & $2 \mathrm{e} /$ aldol condensation $^{\mathrm{b}}$ \\
\hline & $30 \mathrm{~h}, 100^{\circ} \mathrm{C}$ & & $1 f$ & $\mathbf{2 f} /$ aldol condensation $^{\mathrm{b}}$ \\
\hline
\end{tabular}

a $\mathrm{TSC}=$ triple self condensation of three equivalents of the starting substrates $([2+2+2]$ cyclotrimerization), according to results presented later in this research work; ${ }^{b}$ Aldol condensation single-type of aldol condensation between two molecules of the starting ketones, according to results presented later in this research work; ${ }^{a, b}$ According to the mechanism discussed below.

\section{Mechanism}

To the best of our knowledge, two possible mechanisms of acid catalysed [2+2+2] cyclotrimerization of aryland hetaryl methyl ketones have been reported recently. ${ }^{36,37}$ In both approaches, the crucial intermediate, $(E)$ B-methylchalcone/dypnone, was initially formed via the single-type aldol condensation of two equivalents of acetophenones and related compounds activated by the acid catalyst (Scheme 2). ${ }^{34-36}$ Since (E)b-methylchalcones/dypnones were stable compounds, in several cases they were isolated as the final products and the subsequent formation of 1,3,5-trisubstituted benzenes was not observed. The reactivity of (E)-6-methylchalcone/dypnone was crucial in the subsequent cyclization and aromatization reaction sequence, which may occur in the reaction with another amount of the starting carbonyl compound in the single-type aldol condensation (route $A)^{34}$ subsequently followed by intramolecular rearrangement supporting the ring closure (Scheme 2). In the second approach (route $B)^{35}$ the single-type aldol condensation occurs first between 
two equivalents of the $(E)-\beta$-methylchalcone/dypnone, continuing as intramolecular [2+2] cycloaddition and subsequent retro [2+2] cycloaddition leading to 1,3,5-trisubstituted benzenes (Scheme 2). The bulky substituent may inhibit either the aldol condensation with another equivalent of the starting ketone (route $A)^{34}$ or the aldol addition with another equivalent of the dypnone (route B). ${ }^{35}$ The dypnone's ability to precipitate from the reaction mixture as well as the solubility of the carbonyl substrate influences the process of $[2+2+2]$ cyclotrimerization to a large extent. Again, the use of $\mathrm{SiCl}_{4}$ generates $-\mathrm{OSiCl}_{3}$ protected hydroxyl compounds, allowing to stop the addition at the aldol step. ${ }^{17}$

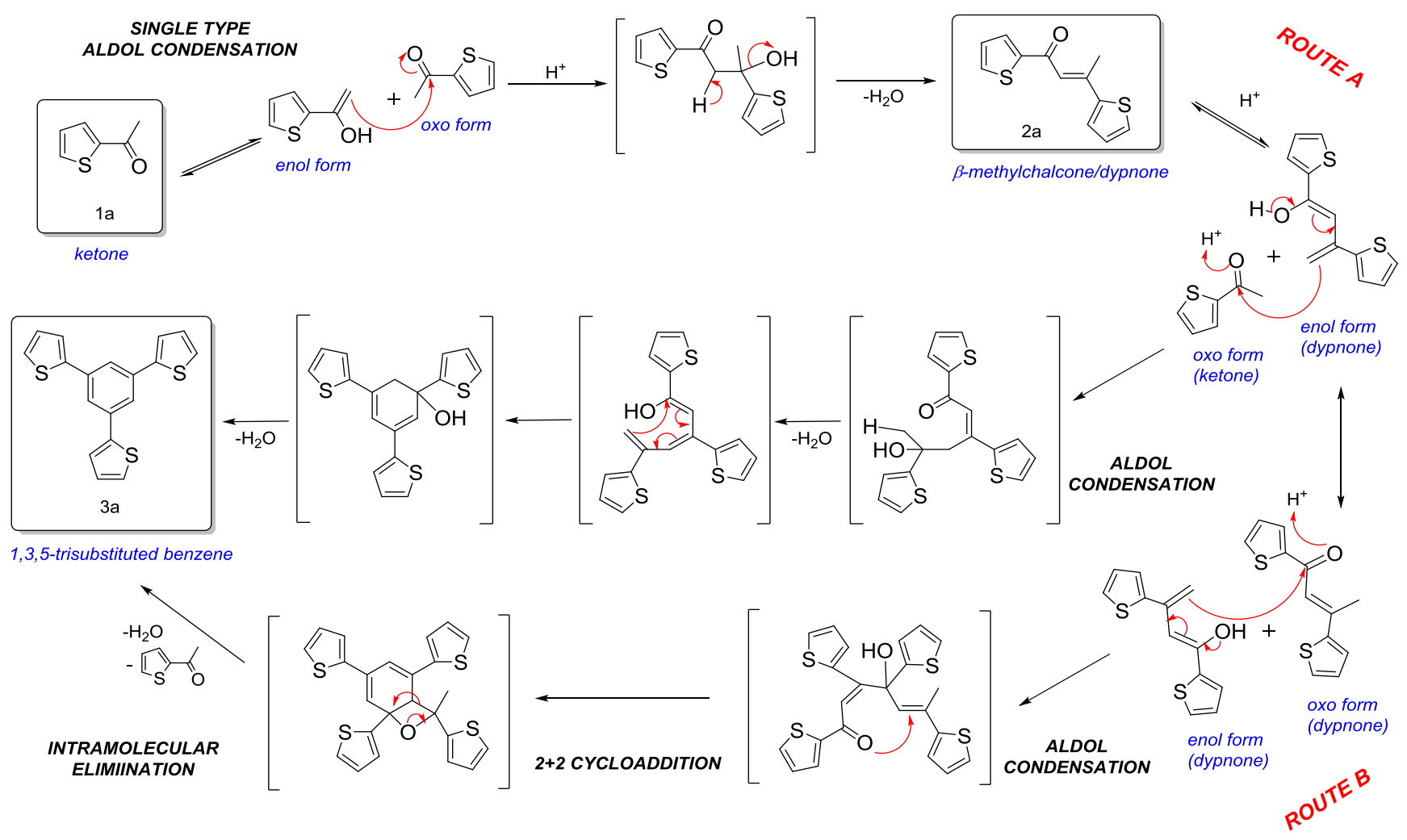

Scheme 2. Proposed mechanism of a triple self-condensation reaction sequence of 1-thien-2-ylethanone (1a). ${ }^{34,35}$ The $\mathrm{H}^{+}$cation originates from dry $\mathrm{HCl}(\mathrm{g})$ which is generated in situ from $\mathrm{SiCl}_{4}$ through the the excited state enolsilyl reactive intermediates. ${ }^{17,34,41}$

\section{Self condensation vs. [2+2+2] cyclotrimerization of starting carbonyl compounds $1 a-f$}

With optimized reaction conditions and insight on the mechanism, the scope of the reaction towards the formation either $C_{3}$-symmetric 1,3,5-trisubstituted benzenes via [2+2+2] cyclotrimerization, or (E)-6methylchalcones/dypnones by the single-type aldol condensation was investigated (Table 2).

The reaction of 1-thien-2-yl-ethanone (1a), 1-(5-methylthien-2-yl)ethanone (1b) and 1-(5-chlorothien-2yl)ethanone (1c) performed under the standard conditions (Method $\mathrm{A}, \mathrm{SiCl}_{4} / \mathrm{EtOH}$ ) affording the 1,3,5trisubstituted benzenes: 1,3,5-tris(thien-2-yl)benzene (3a), 1,3,5-tris(5-methylthien-2-yl)benzene (3b) and 1,3,5-tris-(5-chlorothien-2-yl)benzene (3c), respectively, in yields not exceeding 60\%. The [2+2+2] cyclotrimerization of bromo-substituted derivative $\mathbf{1 d}$ by Method $\mathrm{B}\left(\mathrm{SiCl}_{4}, \mathrm{EtOH} / \mathrm{PhMe}\right)$ produced $C_{3}$-symmetric 1,3,5-trisubstituted benzene $3 \mathbf{d}$ in a moderate $28 \%$ yield, probably as a result of the side polymerization reactions characteristic for bromo-derivatives of thiophenes. By alternating the solvent with 2ethoxyethanol (Method C) for $\mathbf{1 a - 1 d}$ only the reaction with 1a proceeded as $[2+2+2]$ cyclotrimerization leading 
to 1,3,5-tris(thien-2-yl)benzene (3a, 35\%), while in the case of its methyl-, chloro- and bromo-substituted derivatives 1c-1d (E)-6-methylchalcones/dypnones $\mathbf{2 b}$ (33\%), 2c (64\%) and $\mathbf{2 d}$ (31\%) were isolated as a consequence of the single-type aldol condensation. 1,3-Dithienyl-substituted (E)-6-methylchalcone 2a was finally isolated in the yield of 45\% performing the reaction in EtOH/PhMe (50:50) mixture (Method B).

As expected, from the reactions carried out with the 1-(5-fluoren-9-ylidenemethyl)thien-2-yl)ethanone (1e) and the 1-(5-fluoren-9-ylidenemethyl-1-methyl-1H-pyrrol-2-yl)ethanone (1f), bearing the bulky fluorenylidene residues, in PhMe/TFSA (Method D) (E)-6-methylchalcones/dypnones 2e,f were isolated in yield of $33 \%$ in both cases (Table 2). Concerning the substitution, the reaction with $\mathbf{1 e}$, $\mathbf{f}$ was completed as single-type aldol condensation without the formation of any $C_{3}$-symmetric benzenes.

Table 2. Summary of triple self-condensation of heterocyclic methyl ketones 1a-f

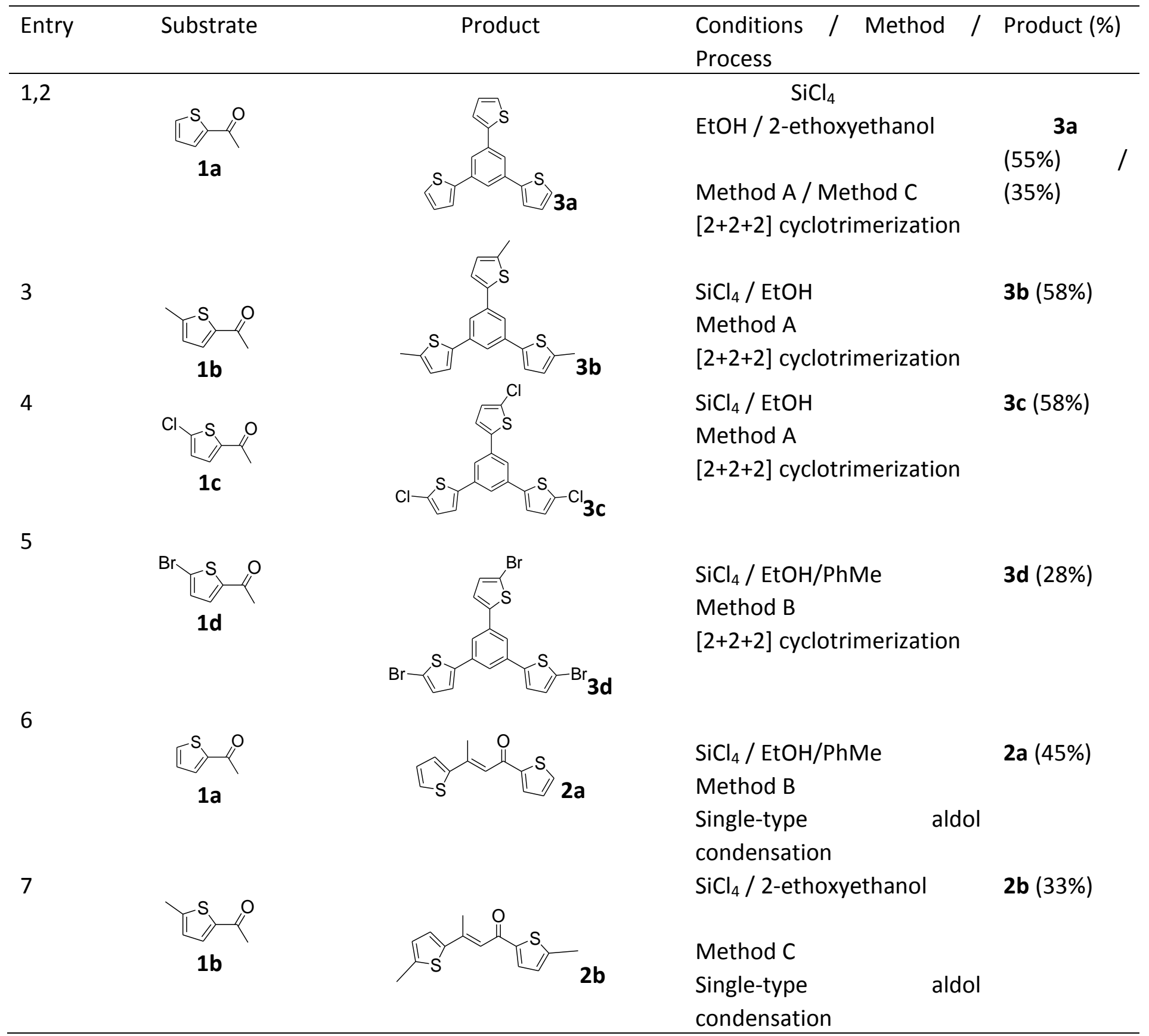


Table 2. Continued

Entry $\begin{aligned} & \begin{array}{l}\text { Conditions / Method / Product (\%) } \\ \text { Process }\end{array} \\ & \mathbf{2 c}(64 \%)\end{aligned}$

\section{Effect of substitution}

To examine effects of the substituent $X$ we have compared the results of formation 1,3,5-triarylbenzene 3a-d and $(E)-6$-methylchalcones $\mathbf{2 a - d}$ from substrates $\mathbf{1 a}(X=H), \mathbf{1} \mathbf{b}(X=M e), \mathbf{1} \mathbf{c}(X=C l)$ and $\mathbf{1 d}(X=B r)(F i g u r e 1)$. Results showed that substrate $1 \mathrm{c}$ possessing chlorine provided best results in both [2+2+2] cyclotrimerization approach towards 1,3,5-trisubstituted benzene 3c as well as in a single-type aldol condensation leading to (E)6-methylchalcone 2c (Entries 4 and 8, Table 2). On the other hand, both types of the reaction with bromosubstituted substrate 1d (Entries 5 and 9, Table 2) were less effective, probably due to the enhanced ability of brominated thiophenes to undergo polymerization. According to generally-accepted fact in comparison with obtained results, we can assume that electron-withdrawing effect of the halogen substituent in the $\alpha$-position (C5) of the thiophene for substrates $\mathbf{1 c}$ and $\mathbf{1 d}(\mathrm{X}=\mathrm{Cl}, \mathrm{Br})$ induced the single-type aldol condensation more efficiently than the triple self-condensation process: $(E)$-6-methylchalcone $2 c$ vs. 1,3,5-trisubstituted benzene $3 c=64 \%$ yield (Entry 8, Table 2) vs. 58\% yield (Entry 4, Table 2); (E)-6-methylchalcone 2d vs. 1,3,5trisubstituted benzene $\mathbf{3 d}=29 \%$ yield (Entry 9, Table 2) vs. $31 \%$ (Entry 5, Table 2), respectively. The most significant effect of the substitution on the reaction proceeding was with subtrates $1 \mathbf{e}$ and $\mathbf{1 f}$ possessing fluorenylidene residue. The steric hindrance inhibited the second aldol reaction towards formation of the benzene ring once appropriate (E)-6-methylchalcones $\mathbf{2 e}(33 \%$, Entry 10, Table 2$)$ and $\mathbf{2 f}$ (33\%, Entry 11, Table 2) are formed. The thienyl methyl ketone without substitution $(\mathbf{1} \mathbf{a}, X=H)$ or bearing methyl substituent $(\mathbf{1 b}, X$ 
$=\mathrm{Me}$ ) proceeded moderately in both, in [2+2+2] cyclotrimerization reaction (43\% and 35\% for 3a, Entry 1 and 2; $41 \%$ for $\mathbf{3 b}$, Entry 3 ) and in a single-type aldol condensation (45\% for $\mathbf{2 a}$ Entry 6; 33\% for $\mathbf{2 b}$, Entry 7 , Table 2).

Taken together, we assumed that the self-condensation reactions of thiophene-based methyl ketones and related compounds were governed by several factors, such as electronic and steric effects of substituents at C5 position of the heterocyclic core together with reaction conditions (Methods A-D) applied for a particular substrate.

1,3,5-Symmetrically-substituted benzenes 3a-d appear in their ${ }^{1} \mathrm{H}$ NMR spectra as singlets at 7.75-7.40 ppm due to aromatic hydrogen and in the range of 7.10-7.75 ppm as doublets or triplets of the thiophene core hydrogens. The $\mathrm{H}-\alpha$ proton of the double bond for $(E)-6$-methylchalcones $2 \mathrm{a}-\mathrm{f}$ resonate in the range of 6.85-7.10 ppm as singlets or quartets as the result of the field interaction between olefinic hydrogen and hydrogen on $\mathrm{C}-\mathrm{B}$ position of the thiophene together with interactions with the neighbouring methyl group. The methyl group signals appeared at $2.50 \mathrm{ppm}$

\section{Mixed-type aldol condensation}

The scope of dypnone-involved organic synthesis was expanded performing the reaction of 2 a (2.0 equiv.) with $p$-fluoroacetophenone (1.0 equiv.) as the aldol-type addition promoted by erbium triflate $\left[\operatorname{Er}(\mathrm{OTf})_{3}, 1.0\right.$ mol \%]. ${ }^{42,43}$ The strong electron-withdrawing capacity of the methanesulfonate anion enhances the Lewis acid character of the catalyst and among the lanthanoid(III) triflates $\mathrm{Er}^{3+}$ was one of the most active cations. ${ }^{44}$ To the best our knowledge, this is the first example of the dypnone-like aldol reaction catalysed by erbium triflate. Unsymmetricaly substituted 1,3,5-benzene $\mathbf{4}$ was isolated after heating at the boiling point of toluene (8 h, 62\%, Scheme 3 ). In the ${ }^{1} \mathrm{H}$ NMR spectrum only aromatic hydrogen signals appear in the range of 8.00 $7.10 \mathrm{ppm}$ indicating the full conversion of the starting $(E)-6$-methylchalcone $\mathbf{2 a}$.
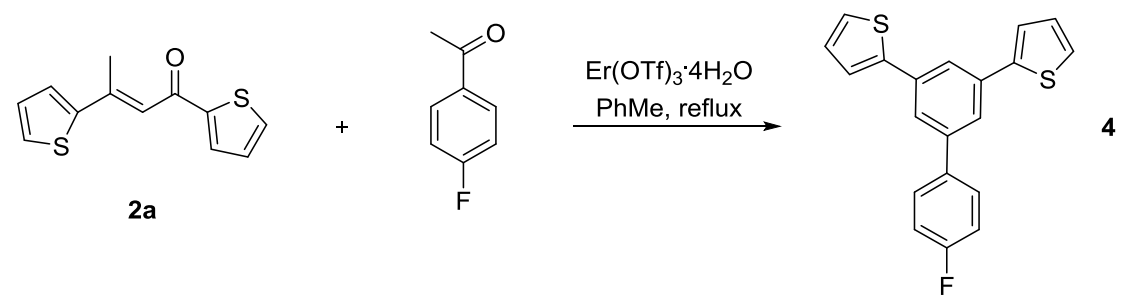

Scheme 3. Mixed-type aldol reaction of 2a forming an unsymmetrically branched 1,3,5-benzene 4 catalysed by erbium triflate.

\section{Conclusions}

In this study we have complemented and compared the known aspects of the $[2+2+2]$ cyclotrimerization reactions of acetophenones and related compounds with our current results. The course of the selfcondensation process is indeed challenging providing the possibility of formation of different type of compounds: the $C_{3}$-symmetric aromatic derivatives or the unsaturated $(E$ )- 6 -methylchalcones (dypnones). We have highlighted, that by varying the substitution of carbonyl substrates in combination with different reaction conditions the reaction can be directed either in a triple [2+2+2] cyclotrimerization manner towards 1,3,5tris(thien-2-yl)benzenes 3a-d (Table 2, Entries 1-5), or in accordance with a single-type aldol condensation producing 1,3-disubstituted (E)-6-methylchalcones 2a-f (Table 2, Entries 6-11). The ability to access new 
compounds $\mathbf{2 b - f}$ through the general and simple protocols (Method B) or by their slight variations (Method C use of ethyleneglycole monoethylether as solvent, Method D - use of trifluoromethane sulfonic acid as acid catalyst) is also described. The outlook of the synthetic application of (E)-6-methylchalcones yielding unsymmetrical 1,3,5-triarylbenzene derivatives is presented on the example of synthesis of $(E)$-3-(2,2'dithienyl)-5-(fluorenyl)benzene (4). Both types of designed structures are important in a broad range of applications; 1,3,5-trisubstituted benzenes in the synthesis of star-shaped molecules acting as the $\pi$-conjugated units in opto-electronic materials and 1,3-disubstituted $(E)$ - 6 -methylchalcones as intermediades in organic synthesis.

\section{Experimental Section}

General. All commercially available chemicals were used as received without further purification. Solvents were purified by standard methods and dried if necessary. Reactions were monitored by thin layer chromatography (TLC) on plates precoated with silica gel (Merck $60 \mathrm{~F}_{254}$ ) and visualized using a UV hand lamp operating at 254/365 nm wavelengths. Melting points were recorded on a Kofler block and are uncorrected. The infrared spectra were taken on Agilent Cary 630 FTIR spectrometer with diamond ATR. Elemental analyses (EA) were performed on a Flash EA 2000 CHNS/O-OEA analyser. ESI-MS spectrum of compound 4 containing fluorine in the structure was recorded on Mass Quattro LC. NMR spectra $\left({ }^{1} \mathrm{H}\right.$ at 300 and ${ }^{13} \mathrm{C}$ at $\left.75 \mathrm{MHz}\right)$ were obtained on the Varian VXR-300 spectrometer and products were reported relative to tetrametylsilane (TMS, $0.00 \mathrm{ppm}$ ) or $\mathrm{CDCl}_{3}$ (7.24 ppm) or DMSO- $d_{6}(2.49 \mathrm{ppm})$ for ${ }^{1} \mathrm{H}$ NMR data, $\mathrm{CDCl}_{3}$ (77.0 ppm) or DMSO-d ${ }_{6}$ (39.7 ppm) for ${ }^{13} \mathrm{C} N M R$ data. Spectral data are presented as follows: chemical shifts in part per million (ppm), coupling constants $J(\mathrm{~Hz})$ and splitting patterns as $\mathrm{s}=$ singlet, $\mathrm{d}=$ doublet, $\mathrm{t}=$ triplet, $\mathrm{q}=$ quadruplet, $\mathrm{dd}=$ doublet of doublets, $\mathrm{m}=$ multiplet. Absorption spectra of the solutions in chloroform $\left(\mathrm{CHCl}_{3}\right)$, or dichloromethane $\left(\mathrm{CH}_{2} \mathrm{Cl}_{2}\right)$ with concentration $1.10^{-5} \mathrm{~mol} \cdot \mathrm{dm}^{-3}$ measured on a UV $1650 \mathrm{PC}$ spectrometer (Shimadzu, Japan).

Thien-2-ylethanone (1a) and its C5 methyl-, chloro-, bromo- and fluorenylidene-substituted derivatives 1b-e were synthesized following the published procedures. ${ }^{45-47} 1-\{5-[(9 H-F l u o r e n e-9-y l i d e n e)$ methyl $]-1-m e t h y l-1 H-$ pyrrol-2-yl\}ethanone (1f) was synthesized in two steps according to Scheme 4 following the acetylation procedure published by us previously. ${ }^{48}$
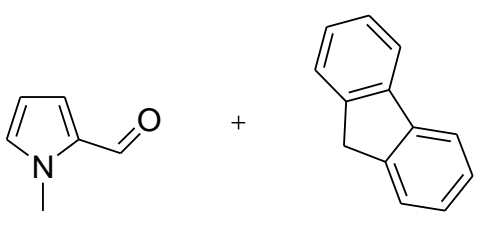
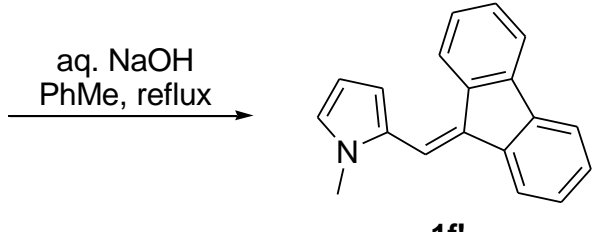

1f'

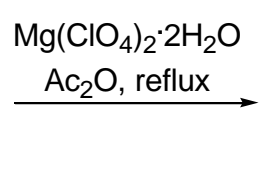

Scheme 4. Synthesis of fluorenylidene-substituted 2-acetyl-1H-methylpyrrole substrate $\mathbf{1 f}$.

1-\{5-[(9H-Fluorene-9-ylidene)methyl]-1-methyl-1H-pyrrol-2-yl\}ethanone (1f). To a solution of 1 -methyl-1Hpyrrole-2-carbaldehyde $(0.06 \mathrm{~mol}, 6.5 \mathrm{~g})$ and fluorene $(0.06 \mathrm{~mol}, 10.0 \mathrm{~g})$ in toluene $(40 \mathrm{~mL})$ sodium hydroxide $(1.4 \mathrm{~mol}, 56.0 \mathrm{~g})$ in water $(84 \mathrm{~mL})$ was added. To the toluene/water mixture the phase transfer catalyst $n$ butyltetraammonium bromide $\left(n-\mathrm{Bu}_{4} \mathrm{NBr}, 0.01 \mathrm{~mol}, 3.5 \mathrm{~g}\right)$ was added and the mixture was left to stir at room 
temperature $\left(25^{\circ} \mathrm{C}\right)$ overnight $(6-8 \mathrm{~h})$. After the reaction was completed the mixture was extracted with toluene $(3 \times 20 \mathrm{~mL})$. Combined organic layers were washed with $0.1 \mathrm{M} \mathrm{HCl}(20 \mathrm{~mL})$, then with water $(2 \times 20$ $\mathrm{mL})$ and finally with saturated solution of $\mathrm{NaCl}(20 \mathrm{~mL})$. The organic layer was dried $\left(\mathrm{Na}_{2} \mathrm{SO}_{4}\right)$ and solvent evaporated under reduced pressure. Crude product was purified by flash column chromatography (eluent: $n$ hexanes/EtOAc, 90:10) to give the intermediate: 2-[(9H-fluorene-9-ylidene)-methyl]-1-methyl-1H-pyrrole (1f') as a yellow oil. Yield 73\% (11.3 g). ${ }^{1} \mathrm{H}$ NMR $\left(300 \mathrm{MHz}, \mathrm{CDCl}_{3}\right) \delta(\mathrm{ppm}) 3.71\left(\mathrm{~s}, 3 \mathrm{H}, \mathrm{N}-\underline{\mathrm{H}}_{3}\right) ; 6.36-6.32(\mathrm{~m}, 1 \mathrm{H}$, pyrrole); $6.80-6.76(\mathrm{~m}, 2 \mathrm{H}$, pyrrole); $7.24-7.22$ (m, $1 \mathrm{H}$, pyrrole); $7.37-7.32$ (m, 4H, fluorenyl); $7.76-7.72$ (m, 3H, fluorenyl); $8.23\left(\mathrm{~d}, J=7.8 \mathrm{~Hz}, 1 \mathrm{H}\right.$, fluorenyl). ${ }^{13} \mathrm{C} \mathrm{NMR}\left(75 \mathrm{MHz}, \mathrm{CDCl}_{3}\right) \delta(\mathrm{ppm}) 34.4,108.5,112.8$, 115.8, 119.5, 119.6, 119.7, 123.7, 124.4, 126.7, 126.8, 127.6, 128.2, 129.0, 134.4, 136.6, 138.6, 139.7, 140.6. Anal. Calc. for $\mathrm{C}_{19} \mathrm{H}_{5} \mathrm{~N}\left(257.33 \mathrm{~g} \cdot \mathrm{mol}^{-1}\right)$ : C, 88.68; H, 5.88; N, 5.44. Found: C, 88.70; H, 6.04; N, 5.22\%. $\lambda_{\max }$ $\left(\mathrm{CHCl}_{3}\right)=250,258,391 \mathrm{~nm}$.

The mixture of 2-[(9H-fluorene-9-ylidene)methyl]-1-methyl-1H-pyrrole (1f', $0.039 \mathrm{~mol}, 10.0 \mathrm{~g})$ in acetic acid anhydride (acting as the solvent and as the acylating agent in the same time, ${ }^{43} 0.039 \mathrm{~mol}, 4.0 \mathrm{~mL}$ ) with magnesium perchlorate dihydrate $\left[\mathrm{Mg}\left(\mathrm{ClO}_{4}\right)_{2} \cdot 2 \mathrm{H}_{2} \mathrm{O}, 0.01\right.$ equiv., $0.39 \mathrm{mmol}, 42 \mathrm{mg}$ ] was left to stir at $80{ }^{\circ} \mathrm{C}$ for $6 \mathrm{~h}$. After the reaction was completed (TLC monitoring) the mixture was poured to ice $(30 \mathrm{~mL})$ and then extracted with diethylether $(3 \times 30 \mathrm{~mL})$. The solvent was evaporated under reduced pressure and crude product was purified by flash column chromatography (eluent: toluene) to give 1-\{5-[(9H-fluorene-9ylidene)methyl]-1-methyl-1H-pyrrol-2-yl\}ethanone (1f) as pale yellow solid. Yield 45\% (5.3 g), mp 150-152 ${ }^{\circ} \mathrm{C}$. ${ }^{1} \mathrm{H}$ NMR $\left(300 \mathrm{MHz}, \mathrm{CDCl}_{3}\right) \delta(\mathrm{ppm}) 2.50\left(\mathrm{~s}, 3 \mathrm{H}, \mathrm{COC}_{\underline{3}}\right), 3.95\left(\mathrm{~s}, 3 \mathrm{H}, \mathrm{NC}_{\underline{3}}\right), 6.56\left(\mathrm{~d}, J_{4,3} 4.2 \mathrm{~Hz}, 1 \mathrm{H}, \mathrm{H}-4_{\text {pyrrole }}\right)$, 7.06 (d, $\left.J_{3,4} 4.2 \mathrm{~Hz}, 1 \mathrm{H}, \mathrm{H}-3_{\text {pyrrole }}\right), 7.13$ (t, J $7.6 \mathrm{~Hz}, 1 \mathrm{H}$, fluorene), 7.24 (s, $1 \mathrm{H}, \mathrm{H}$ - $\left.\alpha_{\text {fluorenylidene }}\right), 7.40-7.27(\mathrm{~m}, 3 \mathrm{H}$, fluorene), $7.68\left(\mathrm{~d}, J 7.8 \mathrm{~Hz}, 2 \mathrm{H}\right.$, fluorene), $7.74\left(\mathrm{~d}, J 7.8 \mathrm{~Hz}, 2 \mathrm{H}\right.$, fluorene). ${ }^{13} \mathrm{C} \mathrm{NMR}(75 \mathrm{MHz}, \mathrm{CDCl})_{3} \delta(\mathrm{ppm})$ 27.5, 34.2, 111.3, 114.0, 118.4, 119.5, 119.7, 119.8, 120.4, 124.2, 127.0, 127.1, 128.8, 129.2, 131.7, 136.0, 137.1, 138.7, 139.3, 139.6, 189.6. Anal. Calc. for $\mathrm{C}_{21} \mathrm{H}_{17} \mathrm{~N}\left(299.37 \mathrm{~g} \cdot \mathrm{mol}^{-1}\right): \mathrm{C}, 84.25 ; \mathrm{H}, 5.72 ; \mathrm{N}, 4.68$. Found: C, 84.35; $\mathrm{H}, 5.66 ; \mathrm{N}, 4.74 \% . \lambda_{\max }\left(\mathrm{CHCl}_{3}\right) 249,261,381 \mathrm{~nm}$.

\section{General procedures of the self-condensation reactions}

METHOD A. To a solution of starting hetaryl methyl ketone 1a-d (1.0 equiv.) in absolute ethanol (30 mL) tetrachlorosilane $\left(\mathrm{SiCl}_{4}, 2.0\right.$ equiv.) was added slowly via the syringe under the inert argon atmosphere at $0{ }^{\circ} \mathrm{C}$. The reaction mixture was left to stir overnight $(14 \mathrm{~h})$ at room temperature $\left(25^{\circ} \mathrm{C}\right)$. The dark reaction mixture was poured into ice water $(100 \mathrm{~mL})$ and stirred for 10 minutes. The aqueous phase was then extracted with $\mathrm{CH}_{2} \mathrm{Cl}_{2}(3 \times 50 \mathrm{~mL})$. The combined organic layers were washed with water $(2 \times 30 \mathrm{~mL})$, saturated solution of $\mathrm{NaCl}(2 \times 20 \mathrm{~mL})$ and then dried $\left(\mathrm{Na}_{2} \mathrm{SO}_{4}\right)$. The solvent was evaporated under reduced pressure and the residue was purified by flash column chromatography.

METHOD B. To a solution of starting hetaryl methyl ketone 1a-d (1.0 equiv.) in absolute ethanol/anhydrous toluene mixture (50:50) tetrachlorosilane $\left(\mathrm{SiCl}_{4}, 3.0\right.$ equiv.) was added slowly via the syringe under the inert argon atmosphere at $0{ }^{\circ} \mathrm{C}$. The reaction mixture was left to stir overnight $(14 \mathrm{~h})$ at room temperature $\left(25^{\circ} \mathrm{C}\right)$. The dark reaction mixture was poured into ice water $(100 \mathrm{~mL})$ and stirred for 10 minutes. The aqueous phase was then extracted with $\mathrm{CH}_{2} \mathrm{Cl}_{2}(3 \times 50 \mathrm{~mL})$. The combined organic layers were washed with water $(2 \times 30 \mathrm{~mL})$, saturated solution of $\mathrm{NaCl}(2 \times 20 \mathrm{~mL})$ and then dried $\left(\mathrm{Na}_{2} \mathrm{SO}_{4}\right)$. The solvent was evaporated under reduced pressure and the residue was purified by flash column chromatography.

METHOD C. To a solution of starting hetaryl methyl ketone 1a-d (1.0 equiv.) in anhydrous 2-ethoxyethanol (30 $\mathrm{mL}$ ) tetrachlorosilane ( $\mathrm{SiCl}_{4}, 4.0$ equiv.) was added slowly via the syringe under the inert argon atmosphere at room temperature. The reaction mixture was left to stir overnight $(14 \mathrm{~h})$ at room temperature $\left(25^{\circ} \mathrm{C}\right)$. The dark reaction mixture was poured into ice water $(100 \mathrm{~mL})$ and stirred for 10 minutes. The aqueous phase was 
then extracted with $\mathrm{CH}_{2} \mathrm{Cl}_{2}(3 \times 50 \mathrm{~mL})$. The combined organic layers were washed with water $(2 \times 30 \mathrm{~mL})$, saturated solution of $\mathrm{NaCl}(2 \times 20 \mathrm{~mL})$ and then dried $\left(\mathrm{Na}_{2} \mathrm{SO}_{4}\right)$. The solvent was evaporated under reduced pressure and the residue was purified by flash column chromatography.

METHOD D. To a solution of starting hetaryl methyl ketone 1e and $\mathbf{1 f}$ (1.0 equiv.) in anhydrous toluene trifluoromethane sulfonic acid (TFSA, $2.0 \mathrm{~mol} \%$ ) was added slowly via the syringe under the inert argon atmosphere at room temperature $\left(25^{\circ} \mathrm{C}\right)$. The reaction mixture was left to stir for $30 \mathrm{~h}$ at $100{ }^{\circ} \mathrm{C}$. Dark reaction mixture was poured to an ice water $(100 \mathrm{~mL})$ and stirred for 10 minutes. Water phase was then extracted with $\mathrm{CH}_{2} \mathrm{Cl}_{2}(3 \times 50 \mathrm{~mL})$. Collected organic layers were washed with water $(2 \times 30 \mathrm{~mL})$, saturated solution of $\mathrm{NaCl}(2 \times 20 \mathrm{~mL})$ and then dried with $\mathrm{Na}_{2} \mathrm{SO}_{4}$. The solvent was evaporated under reduced pressure and the residue was purified by flash column chromatography.

1,3,5-Tris-(thien-2-yl)benzene (3a). Yellow solid, after purification on flash flow column chromatography (eluent: $n$-hexanes). Yield 55\% (6.9 g) starting from 2-acetylthiophene 1a $\left(0.039 \mathrm{~mol}, 4.9 \mathrm{~g} ; \mathrm{SiCl}_{4}: 0.078 \mathrm{~mol}_{\text {, }}\right.$ $13.25 \mathrm{~g}, 9.0 \mathrm{~mL}$, Method A, Entry 1, Table 2). Yield 35\% (4.4 g), starting from 2-acetylthiophene (1a: $0.039 \mathrm{~mol}$, $4.9 \mathrm{~g} ; \mathrm{SiCl}_{4}: 0.156 \mathrm{~mol}, 26.5 \mathrm{~g}, 18.0 \mathrm{~mL}$, Method C, Entry 2, Table 2). Mp 152-156 ${ }^{\circ} \mathrm{C} .{ }^{1} \mathrm{H} \mathrm{NMR}\left(300 \mathrm{MHz} \mathrm{CDCl}_{3}\right)$

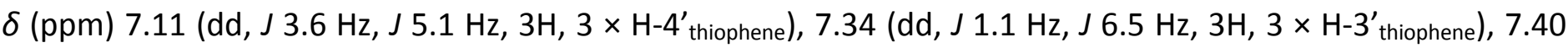
(dd, J $\left.1.1 \mathrm{~Hz}, J 6.5 \mathrm{~Hz}, 3 \mathrm{H}, 3 \times \mathrm{H}-5^{\prime}{ }_{\text {thiophene }}\right), 7.74$ (s, 3H, Ar- $\left.\mathrm{H}_{\text {benzene }}: \mathrm{H}-2, \mathrm{H}-4, \mathrm{H}-6\right) .{ }^{13} \mathrm{C} \mathrm{NMR}\left(75 \mathrm{MHz} \mathrm{CDCl}_{3}\right) \delta$ (ppm) 122.7, 123.9, 125.4, 128.1, 135.7, 143.5. Anal. Calc. for $\mathrm{C}_{18} \mathrm{H}_{12} \mathrm{~S}_{3}\left(324.48 \mathrm{~g} \cdot \mathrm{mol}^{-1}\right): \mathrm{C}, 66.63 ; \mathrm{H}, 3.73 ; \mathrm{S}$, 29.65. Found: C, 66.50; H, 3.48; S, 29.74\%. $\lambda_{\max }\left(\mathrm{CHCl}_{3}\right) 296 \mathrm{~nm}$. The ${ }^{13} \mathrm{C} \mathrm{NMR}$ and UV-Vis spectra are in accordance with Kotha et al. $1999 .^{3}$

1,3,5-Tris-(5-methylthien-2-yl)benzene (3b). Colorless solid, after purification on flash flow column chromatography (eluent: $\mathrm{CH}_{2} \mathrm{Cl}_{2}$ ). Yield 58\% (8.3 g) starting from 1-(5-methylthien-2-yl)ethanone (5-methyl-2acetylthiophene) (1b: 0.039 mol, $5.5 \mathrm{~g}$; SiCl 4 : 0.078 mol, 13.25 g, 9.0 mL, Method A, Entry 3, Table 2). Mp 136$138{ }^{\circ} \mathrm{C} .{ }^{1} \mathrm{H} \mathrm{NMR}\left(300 \mathrm{MHz}, \mathrm{CDCl}_{3}\right) \delta(\mathrm{ppm}) 2.52\left(\mathrm{~s}, 9 \mathrm{H}, 3 \times \mathrm{CH}_{3}\right), 6.75$ (dd, J $3.4 \mathrm{~Hz}, J 6.8 \mathrm{~Hz}, 3 \mathrm{H}, 3 \times \mathrm{H}-3^{\prime}$ thiophene), $6.77\left(\mathrm{~d}, J 6.8 \mathrm{~Hz}, 3 \mathrm{H}, 3 \times \mathrm{H}-4^{\prime}\right.$ thiophene), 7.57 (s, 3H, ArH benzene: $\left.\mathrm{H}-2, \mathrm{H}-4, \mathrm{H}-6\right) .{ }^{13} \mathrm{C} \mathrm{NMR}\left(75 \mathrm{MHz}, \mathrm{CDCl}_{3}\right) \delta(\mathrm{ppm})$ 15.5, 121.7, 123.6, 126.2, 135.7, 140.1, 141.3. Anal. Calc. for $\mathrm{C}_{21} \mathrm{H}_{18} \mathrm{~S}_{3}\left(366.56 \mathrm{~g} \cdot \mathrm{mol}^{-1}\right)$ : C, 68.81; H, 4.95; S, 26.24. Found: $\mathrm{C}, 69.12 ; \mathrm{H}, 4.80 ; \mathrm{S}, 26.36 \% . \lambda_{\max }\left(\mathrm{CHCl}_{3}\right) 305 \mathrm{~nm}$. The ${ }^{13} \mathrm{C}$ NMR and UV-Vis spectra in accordance with Kotha et al. 1999. ${ }^{3}$

1,3,5-Tris-(5-chlorothien-2-yl)benzene (3c). Colorless solid, after purification on flash flow column chromatography (eluent: PhMe). Yield 58\% (9.7 g) starting from 1-(5-chlorothien-2-yl)ethanone (5-chloro-2acetylthiophene) (1c: $0.039 \mathrm{~mol}, 6.2 \mathrm{~g}$; SiCl $4: 0.078 \mathrm{~mol}, 13.25 \mathrm{~g}, 9.0 \mathrm{~mL}$, Method A, Entry 4, Table 2). Mp 172$174{ }^{\circ} \mathrm{C} .{ }^{1} \mathrm{H}$ NMR $\left(300 \mathrm{MHz}, \mathrm{CDCl}_{3}\right) \delta(\mathrm{ppm}) 7.07$ (d, J $6.4 \mathrm{~Hz}, 3 \mathrm{H}, 3 \times \mathrm{H}-4^{\prime}{ }_{\text {thiophene) }} 7.14(\mathrm{~d}, J 6.4 \mathrm{~Hz}, 3 \mathrm{H}, 3 \times \mathrm{H}-$ $3^{\prime}$ thiophene), 7.54 (s, 3H, ArH benzene: $\left.\mathrm{H}-2, \mathrm{H}-4, \mathrm{H}-6\right) .{ }^{13} \mathrm{C} \mathrm{NMR}\left(75 \mathrm{MHz}, \mathrm{CDCl}_{3}\right) \delta(\mathrm{ppm})$ 121.9, 123.2, 127.2, 130.1, 135.2, 141.4. Anal. Calc. for $\mathrm{C}_{18} \mathrm{H}_{9} \mathrm{Cl}_{3} \mathrm{~S}_{3}\left(427.82 \mathrm{~g} \cdot \mathrm{mol}^{-1}\right)$ : C, 50.53; H, 2.12; S, 22.49. Found: C, 50.62; H, 2.10; S, 22.64\%. $\lambda_{\max }\left(\mathrm{CHCl}_{3}\right) 304 \mathrm{~nm}$. The ${ }^{13} \mathrm{C} \mathrm{NMR}$ and UV-Vis spectra in accordance with Kotha et al. $1999 .^{3}$

1,3,5-Tris-(5-bromothien-2-yl)benzene (3d). Colorless solid, after purification on flash flow column chromatography (eluent: PhMe). Yield 28\% (6.1 g) starting from 1-(5-bromothien-2-yl)ethanone (5-bromo-2acetylthiophene) (1d: $0.039 \mathrm{~mol}, 8.0 \mathrm{~g}$; SiCl $4: 0.117 \mathrm{~mol}, 20.0 \mathrm{~g}, 13.5 \mathrm{~mL}$, Method B, Entry 5, Table 2). Mp 112$114{ }^{\circ} \mathrm{C} .{ }^{1} \mathrm{H}$ NMR $\left(300 \mathrm{MHz}, \mathrm{CDCl}_{3}\right) \delta(\mathrm{ppm}) 7.07\left(\mathrm{~d}, J 6.8 \mathrm{~Hz}, 3 \mathrm{H}, 3 \times \mathrm{H}-3^{\prime}{ }_{\text {thiophene }}\right), 7.14(\mathrm{~d}, J 6.8 \mathrm{~Hz}, 3 \mathrm{H}, 3 \times \mathrm{H}-$

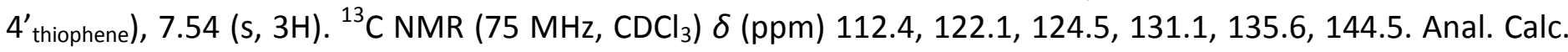
for $\mathrm{C}_{18} \mathrm{H}_{9} \mathrm{Br}_{3} \mathrm{~S}_{3}\left(561.17 \mathrm{~g} \cdot \mathrm{mol}^{-1}\right)$ : C, 38.53; $\mathrm{H}, 1.62 ; \mathrm{S}, 17.14$. Found: C, 38.64; H, 1.80; S, 17.40\%. $\lambda_{\max }\left(\mathrm{CHCl}_{3}\right) 264$ $\mathrm{nm}$. The analytical data are in accordance with Cao et al. ${ }^{49}$

(E)-1,3-Bis-(thien-2-yl)but-2-en-1-one (2a). Pale green-yellow oil, after purification on flash flow column chromatography (eluent: $\mathrm{CH}_{2} \mathrm{Cl}_{2} / i$-hexane, 50:50). Yield 45\% (4.1 g) starting from 2-acetylthiophene (1a: 0.039 mol, $4.9 \mathrm{~g} ; \mathrm{SiCl}_{4}$ : $0.117 \mathrm{~mol}, 20.0 \mathrm{~g}, 13.5 \mathrm{~mL}$, Method B, Entry 6, Table 2). Bp 160-164 ${ }^{\circ} \mathrm{C} / 4.8 \mathrm{~mm} \mathrm{Hg;} \mathrm{mp} \mathrm{70-74}$ 
${ }^{\circ} \mathrm{C} .{ }^{1} \mathrm{H}$ NMR $\left(300 \mathrm{MHz}, \mathrm{CDCl}_{3}\right) \delta(\mathrm{ppm}) 2.50\left(\mathrm{~d}, J 0.4 \mathrm{~Hz}, 3 \mathrm{H}, \mathrm{CH}_{3}\right), 6.12\left(\mathrm{~s}, 1 \mathrm{H}, \mathrm{H}\right.$ - $\left.\alpha_{\text {olefinic }}\right), 7.14$ (dd, J $1.2 \mathrm{~Hz}, J 6.4$ $\mathrm{Hz}, 1 \mathrm{H}, \mathrm{H}-4^{\prime}{ }_{\text {thiophene) }}, 7.22\left(\mathrm{dd}, J 1.6 \mathrm{~Hz}, J 6.8 \mathrm{~Hz}, 1 \mathrm{H}, \mathrm{H}-4^{\prime \prime}{ }_{\text {thiophene }}\right), 7.62\left(\mathrm{~d}, J 6.4 \mathrm{~Hz}, 1 \mathrm{H}, \mathrm{H}-3^{\prime}{ }_{\text {thiophene) }}\right.$ ) 7.65 (d, J

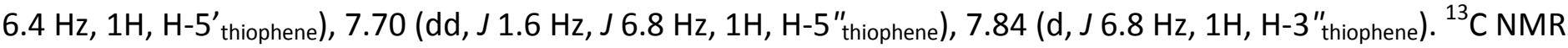
$\left(75 \mathrm{MHz}, \mathrm{CDCl}_{3}\right) \delta(\mathrm{ppm}) 20.4,117.0,125.5,127.2,128.8,129.5,134.8,135.2,136.0,136.2,144.0,151.3$, 182.1. Anal. Calc. for $\mathrm{C}_{12} \mathrm{H}_{10} \mathrm{OS}_{2}\left(234.34 \mathrm{~g} \cdot \mathrm{mol}^{-1}\right)$ : C, 61.50; H, 4.30; S, 27.37. Found: $\mathrm{C}, 61.72 ; \mathrm{H}, 4.55 ; \mathrm{S}, 27.25 \%$. $\lambda_{\max }\left(\mathrm{CH}_{2} \mathrm{Cl}_{2}\right) 268,366 \mathrm{~nm}$.

(E)-1,3-Bis-(5-methylthien-2-yl)but-2-en-1-one (2b). Pale yellow oil, after purification on flash flow column chromatography (eluent: $\mathrm{CH}_{2} \mathrm{Cl}_{2} / \mathrm{i}$-hexane, 50:50). Yield 33\% (3.4 g) starting from 1-(5-methylthien-2yl)ethanone (5-methyl-2-acetylthiophene) (1b: $0.039 \mathrm{~mol}, 5.4 \mathrm{~g} ; \mathrm{SiCl}_{4}: 0.117 \mathrm{~mol}, 20.0 \mathrm{~g}, 13.5 \mathrm{~mL}, \mathrm{Method} \mathrm{B}$, Entry 7, Table 2). Bp $132-136^{\circ} \mathrm{C} / 4.8 \mathrm{~mm} \mathrm{Hg} ; \mathrm{mp} 62-64{ }^{\circ} \mathrm{C} .{ }^{1} \mathrm{H} \mathrm{NMR}\left(300 \mathrm{MHz}, \mathrm{CDCl}_{3}\right) \delta(\mathrm{ppm}) 2.53(\mathrm{~s}, 6 \mathrm{H}, 2 \times$ $\left.\mathrm{CH}_{3}\right), 2.64\left(\mathrm{~s}, 3 \mathrm{H}, \mathrm{CH}_{3}\right), 6.23\left(\mathrm{~s}, 1 \mathrm{H}, \mathrm{H}-\alpha_{\text {olefinic }}\right), 6.75\left(\mathrm{~d}, J 6.5 \mathrm{~Hz}, 1 \mathrm{H}, \mathrm{H}-3^{\prime}\right.$ thiophene), $7.07(\mathrm{~d}, J 6.5 \mathrm{~Hz}, 1 \mathrm{H}, \mathrm{H}-$

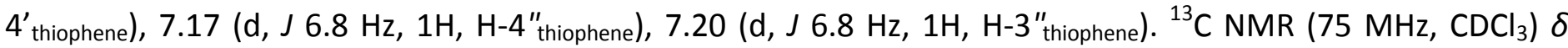
(ppm) 15.9, 16.0, 17.5, 121.3, 126.6, 127.8, 128.7, 129.8, 133.6, 142.6, 145.3, 147.7, 148.9, 182.6. Anal. Calc. for $\mathrm{C}_{14} \mathrm{H}_{14} \mathrm{OS}_{2}\left(265.05 \mathrm{~g} \cdot \mathrm{mol}^{-1}\right): \mathrm{C}, 64.08 ; \mathrm{H}, 5.38 ; \mathrm{S}, 24.44$. Found: $\mathrm{C}, 64.20 ; \mathrm{H}, 5.55 ; \mathrm{S}, 24.75 \% . \lambda_{\max }\left(\mathrm{CH}_{2} \mathrm{Cl}_{2}\right) 255$, $306,363 \mathrm{~nm}$.

(E)-1,3-Bis-(5-chlorothien-2-yl)but-2-en-1-one (2c). Pale yellowish oil, after purification on flash flow column chromatography (eluent: PhMe) or by vaccum distillation. Yield 64\% (7.5 g) starting from 1-(5-chlorothien-2$\mathrm{yl}$ )ethanone (5-chloro-2-acetylthiophene) (1c: $0.039 \mathrm{~mol}, 6.2 \mathrm{~g}$; SiCl 4 : $0.156 \mathrm{~mol}, 26.5 \mathrm{~g}, 18.0 \mathrm{~mL}$, Method C, Entry 8, Table 2). Bp 82-86 ${ }^{\circ} \mathrm{C} / 4.8 \mathrm{~mm} \mathrm{Hg}$; mp 89-92 ${ }^{\circ} \mathrm{C} .{ }^{1} \mathrm{H} \mathrm{NMR}\left(300 \mathrm{MHz}, \mathrm{CDCl}_{3}\right) \delta(\mathrm{ppm}) 2.60(\mathrm{~d}, J 1.2 \mathrm{~Hz}$, $\left.3 \mathrm{H}, \mathrm{CH}_{3}\right), 6.91\left(\mathrm{~d}, J 4.2 \mathrm{~Hz}, 1 \mathrm{H}, \mathrm{H}-\alpha_{\text {olefinic }}\right), 6.94\left(\mathrm{q}, J 1.2 \mathrm{~Hz}, J 6.90 \mathrm{~Hz}, 1 \mathrm{H}, \mathrm{H}-4^{\prime \prime}\right.$ thiophene) $6.96(\mathrm{~d}, J 6.2 \mathrm{~Hz}, 1 \mathrm{H}, \mathrm{H}-$ $\left.4^{\prime}{ }_{\text {thiophene }}\right), 7.19\left(\mathrm{~d}, J 6.2 \mathrm{~Hz}, 1 \mathrm{H}, \mathrm{H}-3^{\prime}{ }_{\text {thiophene }}\right), 7.50\left(\mathrm{~d}, J 6.9 \mathrm{~Hz}, 1 \mathrm{H}, \mathrm{H}-3{ }^{\prime \prime}\right.$ thiophene). ${ }^{13} \mathrm{C} \mathrm{NMR}\left(75 \mathrm{MHz} \mathrm{CDCl}_{3}\right) \delta$ (ppm) 17.4, 116.6, 127.3, 127.5, 130.1, 132.5, 139.1, 144.0, 145.8, 147.8, 181.6. Anal. Calc. for $\mathrm{C}_{12} \mathrm{H}_{8} \mathrm{Cl}_{2} \mathrm{OS}_{2}$ (303.23 g. mol ${ }^{-1}$ ): C, 47.53; H, 2.66; S, 21.15. Found: C, 47.19; $\mathrm{H}, 2.74 ; \mathrm{S}, 21.34 \% . \lambda_{\max }\left(\mathrm{CH}_{2} \mathrm{Cl}_{2}\right) 272,361 \mathrm{~nm}$. The boiling and the melting point are in accordance with Farrar and Levine. ${ }^{50}$

(E)-1,3-Bis-(5-bromothien-2-yl)but-2-en-1-one (2d). Pale yellow-green oil, after purification on flash flow column chromatography (eluent: PhMe) or by vacuum distillation. Yield $31 \%(4.7 \mathrm{~g})$ starting from 1-(5bromothien-2-yl)ethanone (5-bromo-2-acetylthiophene) (1d: $0.039 \mathrm{~mol}, 8.0 \mathrm{~g} ; \mathrm{SiCl}_{4}: 0.156 \mathrm{~mol}, 26.5 \mathrm{~g}, 18.0$ $\mathrm{mL}$, Method C, Entry 9, Table 2). ${ }^{\S} \mathrm{Bp} 98-102^{\circ} \mathrm{C} / 4.8 \mathrm{~mm} \mathrm{Hg} ; \mathrm{mp} 105-107^{\circ} \mathrm{C} .{ }^{1} \mathrm{H} \mathrm{NMR}\left(300 \mathrm{MHz}, \mathrm{CDCl}_{3}\right) \delta(\mathrm{ppm})$ 2.55 (d, J $\left.1.3 \mathrm{~Hz}, 3 \mathrm{H}, \underline{\mathrm{CH}}_{3}\right), 6.95$ (q, J $1.3 \mathrm{~Hz}, 1 \mathrm{H}, \mathrm{H}$ - alefinic $_{\text {) }}, 7.05$ (d, J $6.2 \mathrm{~Hz}, 1 \mathrm{H}, \mathrm{H}-4_{\text {"thiophene) }}^{\prime \prime} 7.10$ (d, J $6.4 \mathrm{~Hz}$, $1 \mathrm{H}, \mathrm{H}-4^{\prime}$ thiophene ), $7.15\left(\mathrm{~d}, J 6.4 \mathrm{~Hz}, 1 \mathrm{H}, \mathrm{H}-3^{\prime}{ }_{\text {thiophene }}\right), 7.45\left(\mathrm{~d}, J 6.2 \mathrm{~Hz}, 1 \mathrm{H}, \mathrm{H}-3{ }^{\prime \prime}\right.$ thiophene). ${ }^{13} \mathrm{C} \mathrm{NMR}\left(75 \mathrm{MHz} \mathrm{CDCl}_{3}\right)$ $\delta$ (ppm) 15.9, 116.8, 127.1, 127.4, 130.2, 130.5, 132.2, 139.8, 140.0, 145.5, 147.9, 182.1. Anal. Calc. for $\mathrm{C}_{12} \mathrm{H}_{8} \mathrm{Br}_{2} \mathrm{OS}_{2}\left(389.84 \mathrm{~g} \cdot \mathrm{mol}^{-1}\right): \mathrm{C}, 37.79 ; \mathrm{H}, 2.06 ; \mathrm{S}, 16.35$. Found: $\mathrm{C}, 38.12 ; \mathrm{H}, 2.44 ; \mathrm{S}, 16.14 \% . \lambda_{\max }\left(\mathrm{CH}_{2} \mathrm{Cl}_{2}\right) 268$, $354 \mathrm{~nm}$.

(E)-1,3-Bis-\{5-[(9H-fluorene-9-ylidene)methyl]thiene-2-yl\}-but-2-en-1-one (2e). Viscous yellow oil, after purification on flash flow column chromatography (eluent: $\mathrm{CH}_{2} \mathrm{Cl}_{2}$ ). Yield 33\% (330 mg). Starting from 1-(5fluoren-9-ylidenemethylthien-2-yl)ethanone (1e: $1.7 \mathrm{mmol}, 500 \mathrm{mg} ; \mathrm{CF}_{3} \mathrm{SO}_{3} \mathrm{H}: 0.1 \mathrm{mmol}, 15 \mathrm{mg}, 9.0 \mu \mathrm{L}$; Method D, Entry 10, Table 2). ${ }^{1} \mathrm{H}$ NMR (300 MHz, DMSO-d 6 ) $\delta(\mathrm{ppm}) 2.65\left(\mathrm{~s}, 3 \mathrm{H}, \mathrm{CH}_{3}\right), 6.85\left(\mathrm{~s}, 1 \mathrm{H}, \mathrm{H}_{\text {fluorenylidene }}\right)$, 6.95 (s, $1 \mathrm{H}, \mathrm{H}_{\text {fluorenylidene) }} 7.05$ (q, J $1.3 \mathrm{~Hz}, 1 \mathrm{H}, \mathrm{H}$ - $\left.\alpha_{\text {olefinic }}\right), 7.30$ (d, J $7.9 \mathrm{~Hz}, 2 \mathrm{H}, \mathrm{H}-3^{\prime}{ }_{\text {thiophene, }} \mathrm{H}-3{ }^{\prime \prime}$ thiophene), 7.83$7.72\left(\mathrm{~m}, 8 \mathrm{H}_{\text {fluorene }}\right), 7.89\left(\mathrm{~d}, \mathrm{~J} 7.7 \mathrm{~Hz}, 2 \mathrm{H}, \mathrm{H}-4^{\prime}\right.$ thiophene, $\mathrm{H}-4{ }^{\prime \prime}$ thiophene), 8.00-8.19 (m, 8 $\left.\mathrm{H}_{\text {fluorene }}\right) .{ }^{13} \mathrm{C} \mathrm{NMR}(75 \mathrm{MHz}$, DMSO- $\left.d_{6}\right) \delta(\mathrm{ppm}) 18.2,117.6,118.5,118.7,119.5,119.9,120.1,120.5,120.7,123.9,124.0,126.9,127.1$, 128.5, 128.6, 128.7, 129.2, 131.2, 131.7, 131.9, 134.8, 134.9, 138.1, 138.3, 138.6, 138.9, 140.7, 140.9, 145.9, 146.7, 147.3, 181.7. Anal. Calc. for $\mathrm{C}_{40} \mathrm{H}_{26} \mathrm{OS}_{2}\left(586.76 \mathrm{~g} \cdot \mathrm{mol}^{-1}\right)$ : C, 81.88; H, 4.47; S, 10.93. Found: $\mathrm{C}, 82.12 ; \mathrm{H}$, $5.00 ; \mathrm{S}, 10.87 \% . \lambda_{\max }\left(\mathrm{CHCl}_{3}\right) 251,259,468 \mathrm{~nm}$. 
(E)-1,3-Bis-\{5-[(9H-fluorene-9-ylidene)methyl]-1-methyl-1H-pyrrole-2-yl\}-but-2-en-1-one (2f). Viscous yellow, after purification on flash flow column chromatography (eluent: $\mathrm{CH}_{2} \mathrm{Cl}_{2}$ ). Yield 33\% (326 mg). Starting from 1\{5-[(9H-fluorene-9-ylidene)methyl]-1-methyl-1H-pyrrole-2-yl\}ethanone (1f: $1.7 \mathrm{mmol}, 510 \mathrm{mg} ; \mathrm{CF}_{3} \mathrm{SO}_{3} \mathrm{H}: 0.1$ mmol, $15 \mathrm{mg}, 9.0 \mu \mathrm{L}$; Method D, Entry 11, Table 2). ${ }^{1} \mathrm{H}$ NMR (300 MHz, DMSO-d $)_{6} \delta$ (ppm) $2.55\left(\mathrm{~s}, 3 \mathrm{H}, \mathrm{CH}_{3}\right)$, $3.46\left(\mathrm{~s}, 6 \mathrm{H}, 2 \times \mathrm{CH}_{3}\right), 6.45\left(\mathrm{~d}, J 3.9 \mathrm{~Hz}, 3 \mathrm{H}, 1 \times \mathrm{H}-\alpha_{\text {olefinic }}, 2 \times \mathrm{H}_{\text {fluorenylidene }}\right), 6.83\left(\mathrm{~d}, J 6.9 \mathrm{~Hz}, 2 \mathrm{H}, \mathrm{H}-4^{\prime}{ }_{\text {pyrrole }}, \mathrm{H}-\right.$ 4" pyrrole), 7.21 (d, J $6.9 \mathrm{~Hz}, 2 \mathrm{H}, \mathrm{H}-3^{\prime}$ pyrrole, $\mathrm{H}-3{ }^{\prime \prime}$ pyrrole), 7.37-7.33 (m, 8H, $\left.8 \times \mathrm{H}_{\text {fluorene }}\right), 7.78-7.73(\mathrm{~m}, 8 \mathrm{H}, 8 \times$ $\mathrm{H}_{\text {fluorene }) .}{ }^{13} \mathrm{C}$ NMR $(75 \mathrm{MHz}$, DMSO-d 6 ) $\delta$ (ppm) 24.2, 32.2, 110.9, 112.8, 112.9, 116.7, 119.8, 119.9, 120.1, $126.9,127.7,128.3,131.4,132.3,136.4,136.5,139.6,140.7,182.0$. Anal. Calc. for $\mathrm{C}_{42} \mathrm{H}_{32} \mathrm{~N}_{2} \mathrm{O}\left(580.72 \mathrm{~g} \cdot \mathrm{mol}^{-1}\right)$ : C, 86.87; H, 5.55; N, 4.82. Found: C, 86.53; H, 5.34; N, 4.67\%. $\lambda_{\max }\left(\mathrm{CHCl}_{3}\right) 252,261,460 \mathrm{~nm}$.

1,3-Bis-(thien-2-yl)-5-(4-fluorophenyl)benzene (4). To a solution of (E)-1,3-bis-(2-thienyl)but-2-en-1-one (2a, $1.22 \mathrm{mmol}, 290 \mathrm{mg}$ ) and 4'-fluoroacetophenone (1.22 mmol, $168.5 \mathrm{mg}, 148 \mu \mathrm{L}$ ) in anhydrous toluene (5 mL) the tetrahydrate of erbium triflate $\left[\operatorname{Er}(\mathrm{OTf})_{3} \cdot 4 \mathrm{H}_{2} \mathrm{O}, 0.12 \mathrm{mmol}, 81.0 \mathrm{mg}\right.$ ] was added. The mixture was stirred at the boiling point of toluene $\left(110^{\circ} \mathrm{C}\right)$ for $6 \mathrm{~h}$ (Scheme 3). Reaction mixture was poured to a water $(10 \mathrm{~mL})$. Water phase was extracted with toluene $(3 \times 15 \mathrm{~mL})$. Collected organic layers were washed with water $(2 \times 10$ $\mathrm{mL})$, saturated solution of $\mathrm{NaCl}(2 \times 10 \mathrm{~mL})$ and then dried $\left(\mathrm{Na}_{2} \mathrm{SO}_{4}\right)$. The solvent was evaporated under reduced pressure and the residue was purified by flash column chromatography (eluent: $n$-hexanes). Yield $62 \%$ (254 mg) of cream-yellow solid. Mp 208-211 ${ }^{\circ} \mathrm{C} .{ }^{1} \mathrm{H}$ NMR $\left(300 \mathrm{MHz}, \mathrm{CDCl}_{3}\right) \delta(\mathrm{ppm}) 7.17(\mathrm{t}, J 6.6 \mathrm{~Hz}, 2 \mathrm{H}, \mathrm{H}-$

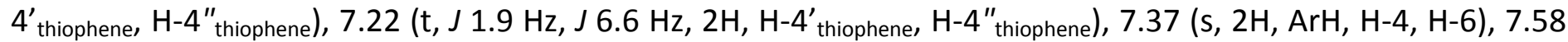

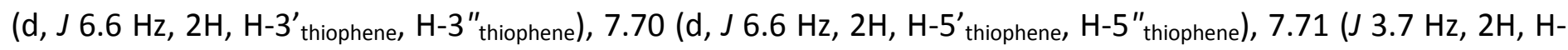
2'"'benzene, H-6'"'benzene), 7.92 (d, J $3.7 \mathrm{~Hz}, 2 \mathrm{H}, \mathrm{H}-3$ '"'benzene, $\mathrm{H}-5$ '"'benzene), 8.21 (s, $1 \mathrm{H}, \mathrm{ArH}, \mathrm{H}-1_{\text {benzene }) .}{ }^{13} \mathrm{C} \mathrm{NMR}(75$ $\left.\mathrm{MHz}, \mathrm{CDCl}_{3}\right) \delta(\mathrm{ppm}) 118.4,124.6,137.7,145.9,153.4,154.7,165.9,175.6,178.9,198.7,198.9 . \mathrm{For} \mathrm{C}_{20} \mathrm{H}_{13} \mathrm{FS}_{2}$ $\left(336.45 \mathrm{~g} \cdot \mathrm{mol}^{-1}\right)(\mathrm{ESI}) \mathrm{m} / \mathrm{z} 337.14\left[\mathrm{M}+\mathrm{H}^{+}\right]$.

\section{Acknowledgements}

This work was financially supported by grants provided by the Ministry of Education of the Slovak Republic, Nos VEGA 1/0534/16; VEGA 2/0161/17 and VEGA 1/0871/16. Financial support of the Slovak Research and Development Agency APVV (contract no. 15-0079) is also acknowledged.

\section{References}

1. Plazek, D. J.; Magill, J. H. J. Chem. Phys. 1966, 45, 3038-3050.

https://doi.org/10.1063/1.1728059

2. Okumoto, K.; Shirota, Y. Appl. Phys. Lett. 2001, 79, 1231-1233.

https://doi.org/10.1063/1.1398325

3. Kotha, S.; Chakraborty, K.; Brahmachary, E. Synlett 1999, 1621-1623.

https://doi.org/10.1055/s-1999-2895

4. Shimasaki, T.; Takyiama, Y.; Nishihara, Y.; Morimoto, A.; Teramoto, N.; Shibata, M. Tetrahedron Lett. 2015, 56, 260-263.

https://doi.org/10.1016/j.tetlet.2014.11.080

5. Jarosz, T.; Lapkowski, M.; Ledwon, P. Macromol. Rapid Commun. 2014, 35, 1006-1032.

https://doi.org/10.1002/marc.201400061 
6. Lee, J. W.; Lee, S. J.; Jho, J. Y.; Lee, J. H. Molecular Cryst. Liquid Cryst. 2015, 621, 70-75. https://doi.org/10.1080/15421406.2015.1095960

7. Sirilaksanapong, S.; Sukwattanasinitt, M.; Rashatasakhon, P. Chem. Commun. 2012, 48, $293-295$. https://doi.org/10.1039/C1CC16148B

8. He, X.; Chen, L.; Zhao, Y.; Ng, S. Ch.; Wang, X.; Sun. X.; Hu, X. (M.) RSC Adv. 2015, 20, 15399-15406. https://doi.org/10.1039/C4RA14934C

9. Suzuki, K.; Seno, A,; Tanabe, H.; Ueno, K. Synth. Met. 2004, 143, 89-96. https://doi.org/10.1016/j.synthmet.2003.10.009

10. Khotina, I. A.; Shapovalov, A. V; Kushakova, N. S.; Sergeev, A. M.; Peregudov, A. S.; Rusanov, A. L.; Babich, S. A.; Bystrova, N. A.; Kovalev, A. I. Polymer. Sci. B 2011, 53, 578-585. https://doi.org/10.1134/S1560090411110030

11. Zhang, S.-L.; Xue Z.-F.; Gao, Y.-R.; Mao, S.; Wang, Y.-Q. Tetrahedron Lett. 2012, 53, 2436-2439. https://doi.org/10.1016/j.tetlet.2012.03.008

12. Tsui, E. Y.; Day, M.W.; Agapie, T. Angew. Chem. Int. Ed. 2011, 50, 1668-1672. https://doi.org/10.1002/anie.201005232

13. Maciejczyk, M. R.; Williams, J. A. G.; Robertson, N.; Pietraszkiewicz, M. RSC Adv. 2017, 7, 49532-49535. https://doi.org/10.1039/C7RA07671A

14. Clapp, D. B.; Morton, A. A. J. Am. Chem. Soc. 1936, 58, 2172-2172. https://doi.org/10.1021/ja01302a025

15. Manna, S.; Antonchick, A. P. Angew. Chem. Int. Ed. 2016, 55, 5290-5293. https://doi.org/10.1002/anie.201600807

16. Dash, J.; Trawnya, D.; Rabec, J. P.; Reissig, H.-U. Synlett. 2015, 26, 1486-1489. https://doi.org/10.1055/s-0034-1380716

17. Rossi, S.; Benaglia, M.; Genoni, A. Tetrahedron 2014, 70, 2065-2080. https://doi.org/10.1016/j.tet.2014.01.055

18. Dash, B. P.; Satapathy, R.; Maguire, J. A.; Hosmane, N. S. Org. Lett. 2008, 10, 2247-2250. https://doi.org/10.1021/ol8005248

19. Gupta, H. K.; Reginato, N.; Ogini, F. O.; Brydges, S.; McGlinchey, M. J. Can. J. Chem. 2002, 80, $1546-1554$. https://doi.org/10.1139/V02-152

20. Cherioux, F.; Guyard, L. Adv. Funct. Mater. 2011, 4, 305-309. https://doi.org/10.1002/1616-3028(200108)

21. Li, Z.; Sun, W.-H.; Jin, X.; Shao, C. Synlett 2001, 1947-1949. https://doi.org/10.1055/s-2001-18771

22. Periasamy, M.; Natarajan Jayakumar, K.; Bharathi, P. J. Org. Chem. 2005, 70, 5420-5425. https://doi.org/10.1021/jo0504215

23. Zhao, Y.; Li, J.; Li, Ch.; Yin, K.; Ye, D.; Jia, X. Green Chem. 2010, 12, 1370-1372. https://doi.org/10.1039/c0gc00158a

24. Zhang, C.-L.; Ye, S. Org. Lett. 2016, 18, 6408-6411. https://doi.org/10.1021/acs.orglett.6b03306

25. Wagh, K. V.; Bhanage B. M. ACS Suss. Chem. Eng. 2016, 4, 4232-4236. https://doi.org/10.1021/acssuschemeng.6b00729

26. Boroujeni, M. B.; Hashemzadeh, A.; Faroughi, M.-T.; Shaabani, A.; Amini, M. M. RSC Adv. 2016, 6, 100195100202. https://doi.org/10.1039/c6ra24574a 
27. Tayebee, R.; Savoji, K.; Razi, M. K.; Maleki, B. RSC Adv. 2016, 6, 55319-55326. https://doi.org/10.1039/c6ra07141d

28. Tayebee, R.; Jarrahi, M. RSC Adv. 2015, 5, 21206-21214. https://doi.org/10.1039/c5ra01344e

29. Zhao, S.; Kang, L.; Ge, H.; Yang, F.; Wang, C.; Li, C.; Wang, Q.; Zhao, M. Synth. Commun. 2012, 42,3569 3578.

https://doi.org/10.1080/00397911.2011.585731

30. Ghanbaripour, R.; Mohammadpoor-Baltork, I.; Moghadam, M.; Khosropour, A. R.; Tangestaninejad, S.; Mirkhani, V. Polyhedron 2012, 31, 721-728.

https://doi.org/10.1016/i.poly.2011.10.027

31. Phatangare, K.; Padalkar, V.; Mhatre, D.; Patil, K.; Chaskar, A. Synth. Commun. 2009, 39, 4117-4121. https://doi.org/10.1080/00397910902885533

32. Ono, F.; Ishikura, Y.; Tada, Y.; Endo, M.; Sato, T. Synlett 2008, 15, 2365-2367. https://doi.org/10.1055/s-2008-1078012

33. Muzart, J. Synth. Commun. 1985, 15, 285-289. https://doi.org/10.1080/00397918508063801

34. Deng, K.; Huai, Q.-Y.; Shen, Z.-L.; Li, H.-J.; Liu, Ch.; Wu, Y.-Ch. Org. Lett. 2015, 17, 1473-1476. https://doi.org/10.1021/acs.orglett.5b00353

35. Wagh, D. G.; Akamanchi, K. G. Tetrahedron Lett. 2017, 58, 3032-3036. https://doi.org/10.1016/i.tetlet.2017.06.055

36. Elmorsy, S. S.; Khalil, A. G. M.; Girges, M. M.; Salama, T. A. Tetrahedron Lett. 1997, 38, 1071-1074. https://doi.org/10.1016/S0040-4039(96)02470-7

37. Clerici, A.; Porta, O. J. Org. Chem. 1985, 50, 76-81. https://doi.org/10.1021/jo00201a015

38. Ott, A. A.; Goshey, Ch. S.; Topczewski, J. J. J. Am. Chem. Soc. 2017, 139, 7737-7740. https://doi.org/10.1021/jacs.7b04203

39. Yamashiro, S.; Imafuku, K. Synth. Commun. 2003, 33, 2757-2762. https://doi.org/10.1081/10426500802589907

40. Badawy, D. S.; Abdel-Galil, E.; Kandeel, E. M.; Basyouni, W. M.; Khatab, T. K. Phosphorus, Sulfur Silicon Relat. Elem. 2009, 184, 2799-1812. https://doi.org/10.1080/SCC-120022162

41. Ramalingan, Ch.; Kwak, Y.-W. Tetrahedron 2008, 64, 5023-5041. https://doi.org/10.1016/i.tet.2008.03.078

42. Dalpozzo, R.; De Nino, A.; Nardi, M.; Procopio, A. Mini Rev. Org. Chem. 2009, 6, 86-94. https://doi.org/10.2174/157019309788167729

43. Procopio, A.; Dalpozzo, R.; De Nino, A.; Maiuolo, L.; Russo, B.; Sindona, G. Adv. Synth. Catal. 2004, 346, 1465-1470. https://doi.org./10.1002/adsc.200404132

44. Tsuruta, H.; Yamaguchi, K.; Imamoto, T. Chem. Commun. 1999, 17, 1703-1704. https://doi.org./10.1039/A905569J

45. He, F.; Wu, H.; Chen, J.; Su, W. Synth. Commun. 2008, 38, 255-264. https://doi.org/10.1080/00397910701750292

46. Altenhöner, K.; Lamm, J.-H.; Mattay, J. Eur. J. Org. Chem. 2010, 6033-6037. https://doi.org/10.1002/ejoc.201000721 
47. Nam, Ng. H.; Buu-Hoï, Ng. Ph.; Xuong, Ng. D. J. Chem. Soc. 1954, 1690-1695.

https://doi.org/10.1039/JR9540001690

48. Andicsová-Eckstein, A.; Tokár, K.; Kozma, E.; Tokárová Z. New. J. Chem. 2017, 48, 14871-14875. https://doi.org/10.1039/c7nj02857a

49. Cao, X.-Y.; Liu, X.-H.; Zhou, X.-H.; Zhang, Y.; Jiang, Y.; Cao, Y.; Cui, Y.-X.; Pei, J. J. Org. Chem. 2004, 69, 60506058.

https://doi.org/10.1021/jo049268p

50. Farrar, M. W.; Levine, R. J. Am. Chem. Soc. 1950, 72, 3695-3698.

https://doi.org/10.1021/ja01164a103 